\title{
AVALIAÇÃO DE PACIENTES QUE REALIZAM COLONOSCOPIA ATRAVÉS DE BUSCA ATIVA
}

\section{INTRODUÇÃO}

Os procedimentos endoscópicos com fins diagnósticos e de tratamento fazem parte da realidade dos serviços de saúde desde a década de 80. ${ }^{1}$ A colonoscopia tornou-se o método de escolha para a avaliação de pacientes com sinais e sintomas sugestivos de doença do cólon. Com essa grande possibilidade terapêutica e diagnostica, o uso da colonoscopia tem aumentado no decorrer dos anos concomitante ao aumento da incidência de complicações. ${ }^{2}$

\section{OBJETIVO}

Mensurar o número de queixas e ou intercorrências em até 12 horas após a realização do exame de colonoscopia.

\section{METODOLOGIA}

Estudo Quanti-qualitativo realizado em um serviço de endoscopia gastrointestinal de uma cidade de médio porte do interior de São Paulo, através da aplicação de um questionário pré-estruturado com questões abertas e fechadas relacionadas ao procedimento e a sedação, realizado pela equipe de enfermagem através de contato telefônico no dia seguinte a realização do exame.

\section{RESULTADOS}

O questionário foi aplicado em 1892 pacientes e as alterações encontradas foram: dor abdominal em 70 casos $(3,69 \%)$, distensão abdominal em 10 casos $(0,5 \%)$, febre em 9 caso $(0,47 \%)$, sangramento 6 casos $(0,31 \%)$, náusea 3 casos $(0,15 \%)$ cefaleia $2(0,12 \%)$ e 1 caso de dor epigástrica $(0,05 \%)$. Em 470 casos $(24,84 \%)$ não foi possível realizar o contato telefônico. Todo o paciente que referiu algum sintoma foi realizado contado no dia seguinte para verificar se o mesmo persistia.

$\begin{array}{ll}\square \text { dor abdominal } & \text { distensão abdominal } \\ \text { febre } & \text { sangramento } \\ \square \text { náusea } & \text { cefaleia } \\ \text { dor epgástrica } & \end{array}$

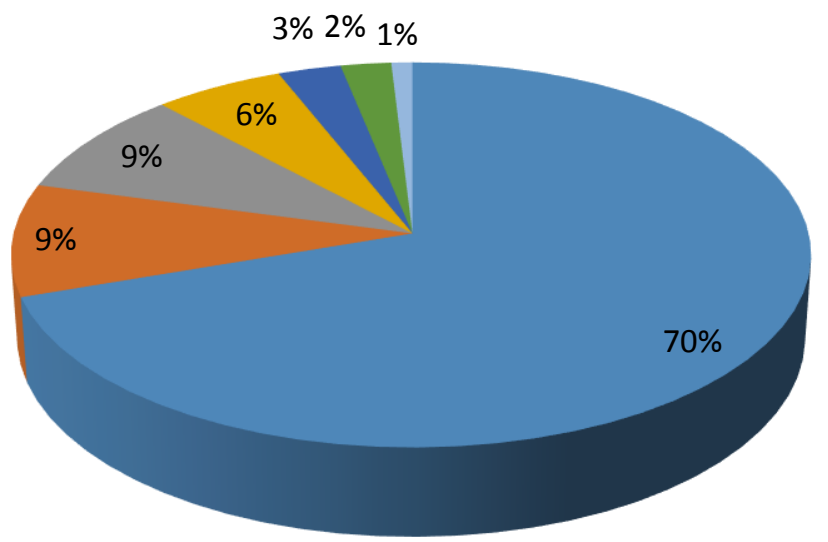

\section{CONCLUSÃO}

Os índices de complicações foram cerca de 5,33\% (101 casos). O item de maior relevância referida pelos pacientes foi relacionado à dor abdominal, tendo 70 casos $(69,30 \%)$. Em vista disso, foram introduzidas como ação, cartas informativas aos médicos Endoscopistas, comunicando a eles a quantidade de queixas que cada seu paciente havia apresentado, visando diminuição dos casos de relatos de dor.

Apesar dos índices serem baixos é importante seu estudo visto que às complicações geradas pelo procedimento de colonoscopia podem levar risco à vida do paciente e espera-se que essa rotina possa promover melhorias continua no serviço.

. Silva MG. Enfermagem em endoscopia digestiva e respiratória. São Paulo: Atheneu, 2010.

2. Warren JL, Klabunde CN, Mariotto AB, Meekins A, Torpor M, Brown ML, Ransohoff DF. Adverse events after outpatient colonoscopy in the medicare population. Ann Intern Med. 2009;150(12):849-858

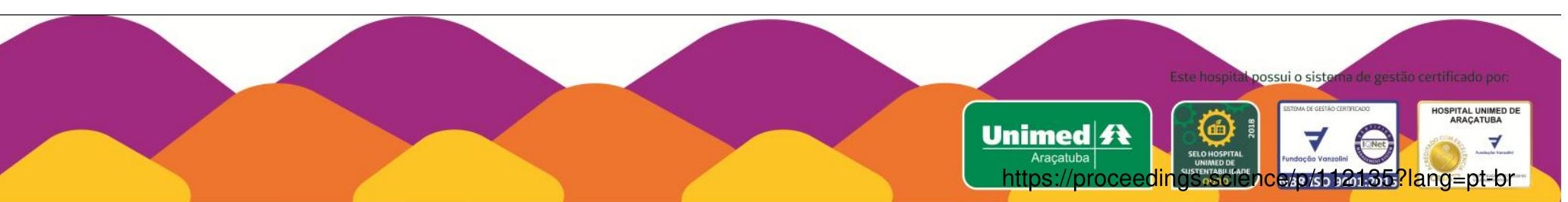

